\title{
Penilaian Keberlanjutan UKM Batik Kota Semarang dengan Metode Product Service System
}

\author{
Ratna Purwaningsih ${ }^{*}$, Mahardhika Cakra Yudha ${ }^{1}$, Novie Susanto ${ }^{1}$
}

\begin{abstract}
Small Medium Enterprises (SME) of Batik Semarang still focus on maintain their business to get more profits. Sustainability aspect has not received enough attention yet. This study aims to review the sustainability level of SME Batik Semarang using product service system (PSS) method. PSS consists of three dimension (1) Environment, (2) Socio-cultural and (3) Economic. Each dimension consist of 6 criteria's. PSS does not only assess the level of sustainability but also formulats the recommendation to increase the sustainability level using the industry system map and SWOT analysis. Formulation of these recommendation are guidance by a check list form. Then, the portfolio diagram used to select these recommendations according to its feasibility to be implemented and its importance for the industry. Result of sustainability assessment for SME Batik give the average of sustainability level value 0.103 , categorized as lob level. The recommendations for the environmental dimension are (1) optimization on using the raw materials and water, (2) recycling the waste of dyes, and (3) use a bio-degradable material. Recommendation for socio-cultural dimension is use personal protective tool for workers. Recommendation for economic dimension is to specify market target groups, produce more attractive products and create diversification way for supply of batik for the consumers. Recommendations are then illustrated in a diagram in the form of radar sustainability.
\end{abstract}

Keywords: SME batik Semarang; sustainability; product-service system method; formulation of recommendation.

\section{Pendahuluan}

Pembangunan berkelanjutan merupakan pembangunan yang berusaha memenuhi kebutuhan hari ini, tanpa mengurangi kemampuan generasi mendatang untuk memenuhi kebutuhannya (WECD [1]). Penilaian tingkat keberlanjutan dari suatu wilayah ataupun suatu unit bisnis telah dikembangkan pada berbagai bidang. Pada sektor pertambangan dan mineral telah dikembangkan indikator keberlanjutan oleh Mining, Minerals and Sustainable Development (MMSD). Pada sektor kehutanan penilaian dampak keberlanjutan rantai pasok kayu hutan diukur menggunakan ToSIA ( $A$ Tool for Sustainability Impact Assessment) (Palosuo et al. [2]). Pada sektor kimia faktor karakterisasi untuk ekotoksisitas dan toksisitas manusia diukur dengan metode Uniform System for the Evaluation of Substance (USES-LCA) (Jager et al. [3]). Faktor karakterisasi ekotoksikologi tersedia untuk ekosistem darat, laut dan air tawar sedangkan toksisitas manusia memperhitungkan baik karsinogen dan faktor non-karsinogen (Angelakoglou et al. [4]).

\footnotetext{
${ }^{1}$ Fakultas Teknik, Jurusan Teknik Industri, Universitas Diponegoro, Jl. Prof. Soedharto, SH, Tembalang, Semarang. Indonesia.

Email: ratna.tiundip@gmail.com, nophie.susanto@gmail.com

* Penulis korespondensi
}

Pada sektor Industri identifikasi keberlanjutan telah dikem bangkan metode Indicators of Sustainable Development for Industry (ISDI). Keberlanjutan dinilai melalui empat belas indikator kuantitatif dan empat indikator kualitatif yang diklasifikasikan ke dalam tiga kategori: dampak lingkungan, efisiensi lingkungan dan tindakan sukarela. ISDI mengikuti pendekatan siklus hidup, dengan mempertimbangkan siklus hidup lengkap bahan dan energi dimanfaatkan (Azapagic [5]).

Salah satu metode untuk menilai keberlanjutan industri yang lebih berfokus pada identifikasi rekomendasi perbaikan yang dapat disarankan untuk meningkatkan keberlanjutan industri adalah PSS (Product-Service System). Pendekatan PSS adalah pengembangan dari design for sustainability atau D4S. Konsep 'Desain untuk Keberlanjutan' (D4S) berisi tentang bagaimana membuat produk 'hijau' dan bagaimana memenuhi kebutuhan konsumen dengan cara yang lebih berkelanjutan. D4S mempertimbangkan bahwa proses desain dan proses produksi tidak hanya memperhitungkan masalah lingkungan tetapi juga masalah sosial dan ekonomi. Kriteria dalam D4S disebut sebagai tiga pilar keberlanjutan, yaitu people, profit and planet. People berkaitan dengan keadaan sosial, profit berkaitan dengan keadaan ekonomi, dan planet berkaitan dengan keadaan lingkungan. 
Perusahaan menggunakan konsep D4S dalam mengembangkan strategi inovasi produk jangka panjang untuk mengurangi dampak negatif terhadap aspek lingkungan, sosial, dan ekonomi dalam rantai pasok produk dan sepanjang siklus hidup produk. D4S bertujuan untuk meningkatkan efisiensi dan kualitas dari proses produksi dalam pengembangkan produk, jasa, dan sistem produksi. Terdapat tiga pendekatan dalam konsep D4S yaitu redesign, pengembangan produk baru dan Sistem Produk-Servis (PSS). Redesign membahas mengenai bagaimana merancang produk yang sudah ada agar lebih berkelanjutan, pengembangan produk baru membahas mengenai bagaimana membuat produk baru menjadi produk yang berkelanjutan, dan PSS membahas mengenai bagaimana merancang suatu sistem produk dan jasa yang berkelanjutan (UNEP [6]).

Product-Service System dapat didefinisikan sebagai hasil pergantian fokus suatu bisnis dari membuat dan menjual produk fisik saja menjadi menjual suatu sistem dari produk dan jasa yang dapat memenuhi permintaan konsumen dengan memperhatikan aspek sosial, ekonomi, dan lingkungan. Konsep dari PSS adalah strategi bisnis yang memungkinkan dan menjanjikan untuk menuju masyarakat yang lebih berkelanjutan karena tujuan dari PSS adalah mengintegrasikan lingkungan dengan aspek sosial dan ekonomi yang terjadi. Dengan menggunakan PSS, dapat diketahui bagaimana produk dan jasa dapat dikembangkan bersama dengan mempertimbangkan aspek sosial, lingkungan dan ekonomi untuk menuju industri yang berkelanjutan (Tischner [7]). PSS terdiri dari tiga dimensi keberlanjutan yang akan dijadikan dasar untuk menyusun rekomendasi. Ketiga dimensi tersebut yaitu dimensi lingkungan, sosial-budaya dan ekonomi. Dimensi lingkungan menitikberatkan pada efisiensi penggunaan sumber daya dan mengurangi dampak negatif pada lingkungan. Dimensi sosial budaya fokus meningkatkan keselamatan dan kesejahteraan para pekerja dan masyarakat pengguna produk atau konsumen dan dimensi ekonomi fokus pada upaya upaya meningkatkan keuntungan ekonomi bagi industri (Crul and Diehl [8]).

Salah satu industri yang perkembangannya pesat di Indonesia adalah industri batik, yang merupakan salah satu karya seni paling terkemuka dan kerajinan tangan tradisional bernilai tinggi. Nilai ekspor batik dan produksi batik yang terus meningkat, dari hanya USD 32 juta pada 2008 menjadi USD 278 juta pada 2012. Industri batik di Indonesia berkembang pesat setelah pada 2 Oktober 2009 mendapat pengakuan dari UNESCO sebagai warisan budaya dunia asal Indonesia (Andayani et al.[9]). Industri batik merupakan sumber pendapatan masyarakat di berbagai kota, seperti Pekalongan, Solo, Jogjakarta, Cirebon, Semarang dan daerah lain (Djoemena [10]). Industri batik di kota Semarang masih menggunakan malam, pewarna sintetis secara berlebihan yang disebabkan karena proses produksi yang tidak efisien (Soekardan et al. [11]). Hal ini diperburuk karena proses daur ulang limbah maupun bahan baku batik tidak dilakukan secara maksimal oleh pengrajin batik Kota Semarang. Menurut Kurniawan [12] industri batik merupakan industri yang potensial menghasilkan limbah yang mengandung logam berat dan limbah cair yang berbahaya yang dapat menyebabkan pencemaran lingkungan.

Proses produksi yang berkelanjutan tidak hanya memperhatikan efek samping dari limbah sisa prosesnya, namun juga mereduksi limbah buangan yang dihasilkan. Posisi pasar dan profitabilitas yang masih rendah menjadikan pengrajin batik Semarang belum memberi perhatian yang cukup pada aspek lingkungan. Oleh sebab itu, sangat penting bagi para pengrajin UKM batik Semarang untuk memperhatikan aspek-aspek keberlanjutan dalam tiap proses produksi yang dilaksanakan agar dapat menciptakan keserasian dengan lingkungan, ekonomi dan sosial-budaya atau yang biasa disebut triple bottom line (Putranti [13]). Tujuan dari penelitian ini adalah (1) Mengidentifikasi dimensi keberlanjutan pada UKM Batik di kota Semarang menggunakan metode PSS, (2) Merumuskan rekomendasi untuk kriteria keberlanjutan yang perlu ditingkatkan, (3) Melakukan evaluasi dan pengujian terhadap rekomendasi yang dirumuskan guna meningkatkan keberlanjutan dari industri batik di kota Semarang

\section{Metode Penelitian}

Penelitian ini dilakukan pada sentra UKM Batik Kota Semarang selama bulan April 2015. Berdasarkan data dari pengurus klaster UKM Batik Kota Semarang hingga saat ini terdapat sekitar 26 anggota klaster usaha batik yang terus aktif. Namun penelitian hanya dilakukan pada sembilan UKM karena memiliki kapasitas produksi cukup besar dan memiliki pekerja. UKM yang tergolong sedang dan kecil dimanaUKM tersebut tidak memiliki pekerja dan proses produksi dilakukan sendiri oleh pemilik sebab skala produksinya terlalu kecil. Selain itu, sembilan UKM tersebut merupakan pengrajin batik, berbeda dengan beberapa UKM yang hanya melakukan penjualan batik saja tanpa memproduksi batik untuk kemudian dipasarkan. Jumlah tenaga kerja per UKM antara 3 sampai 20 orang baik tenaga kerja tetap dan borongan dengan rentang usia antara 32 -sampai 57 tahun. Metode penelitian dilakukan dengan observasi langsung, wawancara dan pengisian kuisioner oleh pengelola UKM. 


\section{Methodologi Production and Service System}

\section{Identifikasi kriteria dan indikator keberlanjutan sistem produk/jasa}

\section{Peta sistem}

Menggambarkan aliran informasi, material, dan antar hubungan antara unit bisnis dengan semua pihak terkait dari pemasok hingga pembeli.

Mengidentifikasi masalah

keberlanjutan dalam sistem industri.

\section{SWOT Keberlanjutan}

Identifikasi kekuatan, kelemahan

yang ada pada masa sekarang

(existing condition) dan

memprediksi peluang dan

ancaman untuk masa mendatang

(future condition)

\section{Penilaian Keberlanjutan}

Menggunakan PSS Checklist

Untuk analisa kondisi

keberlanjutan sistem dan

identifikasi prioritas perbaikan.

Melakukan kategorisasi kriteria

sistem dalam 4 kelas

(No, Low, Medium, High)

\section{Merumuskan rekomendasi}

2 Berdasarkan hasil penilaian dari lembar kerja PSS dari tahap 1 dirumuskan rekomendasi perbaikan untuk meningkatkan keberlanjutan industri

$3 \begin{aligned} & \text { Mengembangkan detail rekomendasi } \\ & \text { Melakukan perincian rekomendasi menjadi program kerja } \\ & \text { atau aktivitas teknis yang dapat dilaksanakan }\end{aligned}$

Membandingkan rekomendasi dengan kondisi sistem saat ini

Pemilihan Rekomendasi

4 Analisa kelayakan rekomendasi dengan Portfolio Diagram

dari aspek keberlanjutan and Kemungkinan untuk

dilaksanakan (Feasibility)

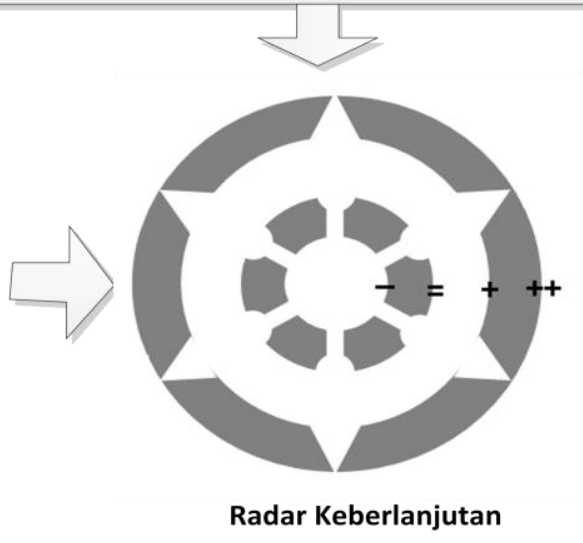

Gambar 1. Tahapan dalam PSS

Metode penilaian keberlanjutan dan perumusan rekomendasi dengan metode PSS dilakukan dengan serangkaian tahapan yang dikembangkan oleh UNEP dan DELFT University of Technology [6]. PSS terdiri dari 4 tahapan yaitu (1) Mengidentifikasi dimensi keberlanjutan sistem, (2) Merumuskan dan memilih rekomendasi, (3) Melakukan penilaian terhadap detail rekomendasi (4) Melakukan evaluasi pada rekomendasi untuk memilih yang terbaik. Purwaningsih [14] merangkum aktivitas dalam setiap tahapan PSS dan menggambarkan secara umum metode PSS seperti pada Gambar 1.

Pada Gambar 1 dapat dilihat bahwa tahap pertama PSS adalah mengidentifikasi dimensi keberlanjutan sistem. Pada tahap ini dilakukan pengenalan terhadap sistem industri yang dipelajari dengan memperhatikan aspek internal dan eksternal dengan membuat peta sistem, membuat diagram SWOT keberlanjutan (identifikasi strength dan weakness untuk kondisi sekarang serta identifikasi opportunity dan threat untuk masa mendatang), dan penilaian keberlanjutan dengan menggunakan lembar kerja PSS. Jadi, tahap pertama ini terdiri dari tiga aktivitas berikut ini : (1) Menggambar peta sistem berfungsi untuk mengidentifikasi aktor yang terlibat dalam perusahaan seperti pemasok bahan baku, konsumen, dan pedagang batik serta mengidentifikasi aliran material serta aliran informasi di dalamnya. (2) Membuat SWOT keberlanjutan berfungsi untuk mengidentifikasi kekuatan, kelemahan, peluang, dan ancaman yang dimiliki oleh perusahaan. Analisis SWOT ini sendiri mencakup lima aspek, yaitu lingkungan, sosial budaya, ekonomi, teknologi, dan legislasi/ regulasi. (3) Menilai industri dengan checklist untuk menganalisis kriteria-kriteria dalam sistem yang belum memenuhi aspek berkelanjutan dengan 3 dimensi dan setiap dimensi terdiri dari 6 kriteria.

Tahap kedua dalam PSS adalah merumuskan dan memilih rekomendasi yang dilakukan dengan bantuan lembar kerja (worksheet) PSS dan portofolio diagram untuk penilaian kelayakan rekomendasi. Lembar kerja PSS berisi pilihan untuk mengarahkan rekomendasi. Berikutnya adalah membuat Diagram Kelayakan Rekomendasi yang digunakan untuk melihat apakah rekomendasi yang ditawarkan layak dan mengandung aspek berkelanjutan untuk sistem atau tidak. Faktor-faktor yang dipertimbangkan antara lain kemungkinan untuk melakukan perubahan pada faktor teknologi, pengu- 
rangan penggunaan sumber daya, minimasi limbah, kemungkinan daur ulang, bio compatibility, peluang kerjasama dengan pihak luar untuk meningkatkan akses pasar dan bahan baku produksi.

Tahap ketiga adalah mengembangkan detail rekomendasi terpilih yang dilakukan dengan: (1) Mengidentifikasi prioritas kriteria rekomendasi $(\mathrm{H}=$ Tinggi, $\mathrm{M}=$ Sedang, $\mathrm{L}=$ Rendah dan $\mathrm{N}=$ Tidak ada). (a) Identifikasi dilakukan dengan bantuan lembar kerja PSS yang diisi dengan jawaban "Ya" dan "Tidak" oleh responden. Jawaban "Ya" memiliki skor 1 dan jawaban "Tidak" memiliki skor 0. Maka, maksimal skor dari sebuah kriteria adalah banyaknya pertanyaan pada kriteria tersebut (jika semua dijawab Ya) dan minimal skor dari setiap kriteria adala nol (Jika semua dijawab tidak). (b) Bagi jawaban "Ya" dari setiap responden dengan maksimal skor dari kriteria tersebut dan didapatkan skor berupa pecahan (antara 0 sampai 1). Kemudian lakukan perhitungan kategoriasi kriteria dilakukan dengan langkah seperti berikut: (b1) Tentukan skor tertinggi dan terendah untuk setiap kriteria. Nilai tertinggi tiap kriteria adalah sama dengan jumlah butir pertanyaan untuk kriteria tersebut dan nilai terendah adalah nol. (b2) Tentukan nilai rentang skor (nilai tertinggi - nilai terendah), bagi tiga rentang skor untuk mendapat interval nilai Tinggi, Sedang, dan Rendah. (b3) Kategorikan kondisi tiap kriteria. Misalkan sebuah kriteria memiliki nilai 1 dibagi dengan 3 didapatkan hasil 0,33. Maka, kategori Rendah memiliki interval skor dari 0-0,33, kategori Sedang memiliki interval skor dari 0,34-0,66 dan interval Tinggi memiliki interval skor dari 0,671 (Arikunto [15]. (2) Merinci rekomendasi dengan bantuan pedoman (lembar kerja). Kriteria dengan prioritas tinggi dan menengah harus lebih dipertimbangkan.

Tahap keempat melakukan evaluasi dan memilih rekomendasi terpilih. Tahap ini dilakukan dengan membuat portofolio diagram dan radar PSS yang berfungsi untuk membandingkan kondisi jika rekomendasi tersebut diterapkan dengan sistem saat ini. Langkah untuk membuat portofolio diagram yang merupakan diagram evaluasi kelayakan rekomendasi adalah: (a) Posisikan semua rekomendasi dalam matriks, kemudian diskusikan dengan pengelola UKM mengenai kelayakannya implementasinya. (b) Lakukan perangkuman semua hasil rekomendasi ke dalam diagram portofolio PSS. Diagram ini memiliki sumbu y untuk keberlanjutan dan sumbu x untuk kelayakan/implementasi. (c) Semua rekomendasi dibandingkan satu sama lain dan dengan mempertimbangkan semua rekomendasi sebelumnya yang telah dilakukan. (d) Posisikan rekomendasi dalam diagram menurut potensi tertinggi sampai terendah dari aspek keberlanjutan dan kelayakan implementasi. Rekomendasi di bagian kanan atas merupakan rekomendasi terbaik.

Hasil dari evaluasi rekomendasi ini kemudian dipetakan dalam radar keberlanjutan untuk setiap dimensi.

\section{Hasil dan Pembahasan}

\section{Dimensi Keberlanjutan Sistem}

Peta sistem berfungsi untuk mengidentifikasi alur informasi serta material yang ada pada sistem, mengidentifikasi pihak-pihak yang berkaitan langsung dalam sistem produksi batik, misalnya pemasok bahan baku batik, konsumen, dan pedagang batik. Peta sistem dari UKM Batik Kota Semarang secara umum dapat dilihat pada Gambar 2.

Langkah berikutnya adalah melakukan penilaian SWOT dan menyusun hasilnya dalam diagram untuk mengidentifikasi kekuatan, kelemahan yang dimiliki perusahaan di masa sekarang serta peluang dan ancaman yang dimiliki oleh perusahaan di masa yang akan datang. Diagram SWOT ini dihasilkan dari wawancara kepada pemilik UKM batik kota Semarang. Diagram SWOT UKM batik kota Semarang secara rinci dapat dilihat pada Tabel 1. Butir-butir pertanyaan untuk SWOT ini mengacu pada 6 kriteria dari 3 dimensi PSS, serta catatan catatan lain diluar kriteria yang dianggap penting. SWOT ini adalah hasil wawancara dengan 9 pengelola UKM batik dengan pertanyaan terbuka. Jawaban responden yang bervariasi kemudian diidentifikasi pola kesamaannya dan dirangkum sebagai diagram SWOT. Diagram ini nantinya berguna dalam melakukan identifikasi rekomendasi perbaikan sistem.

Langkah berikutnya, dilakukan kategorisasi kriteria keberlanjutan dalam kategori Low (L), Medium (M) atau $\operatorname{High}(\mathrm{H})$ untuk mengetahui kriteria yang perlu dikembangkan. Penilaian dilakukan dengan memberikan kuisioner kepada pemilik UKM Batik dan pegawai. Berikutnya, dilakukan pengolahan data atas jawaban dari setiap responden. Jawaban "Ya" memiliki skor 1 dan jawaban "Tidak" memiliki skor 0. Jika suatu kriteria tidak dimungkinkan untuk dirumuskan rekomendasi maka dianggap tidak ada pengaruh (No, N). Total nilai tiap kriteria merupakan penjumlahan dari jumlah nilai 1 dalam pertanyaan yang diberikan untuk tiap kriteria. Misalnya Jika ada 2 jawaban "Ya" dalam 4 butir pertanyaan tentang optimasi umur sistem, maka nilainya adalah $2 / 4$ atau 0,5 . Setelah dilakukan perhitungan nilai untuk tiap dimensi, kemudian dilakukan kategorisasi dengan melihat rata-rata skor dari setiap kriteria. Rekapitulasi hasil penilaian tiap kriteria tiap UKM diberikan pada Tabel 2. 


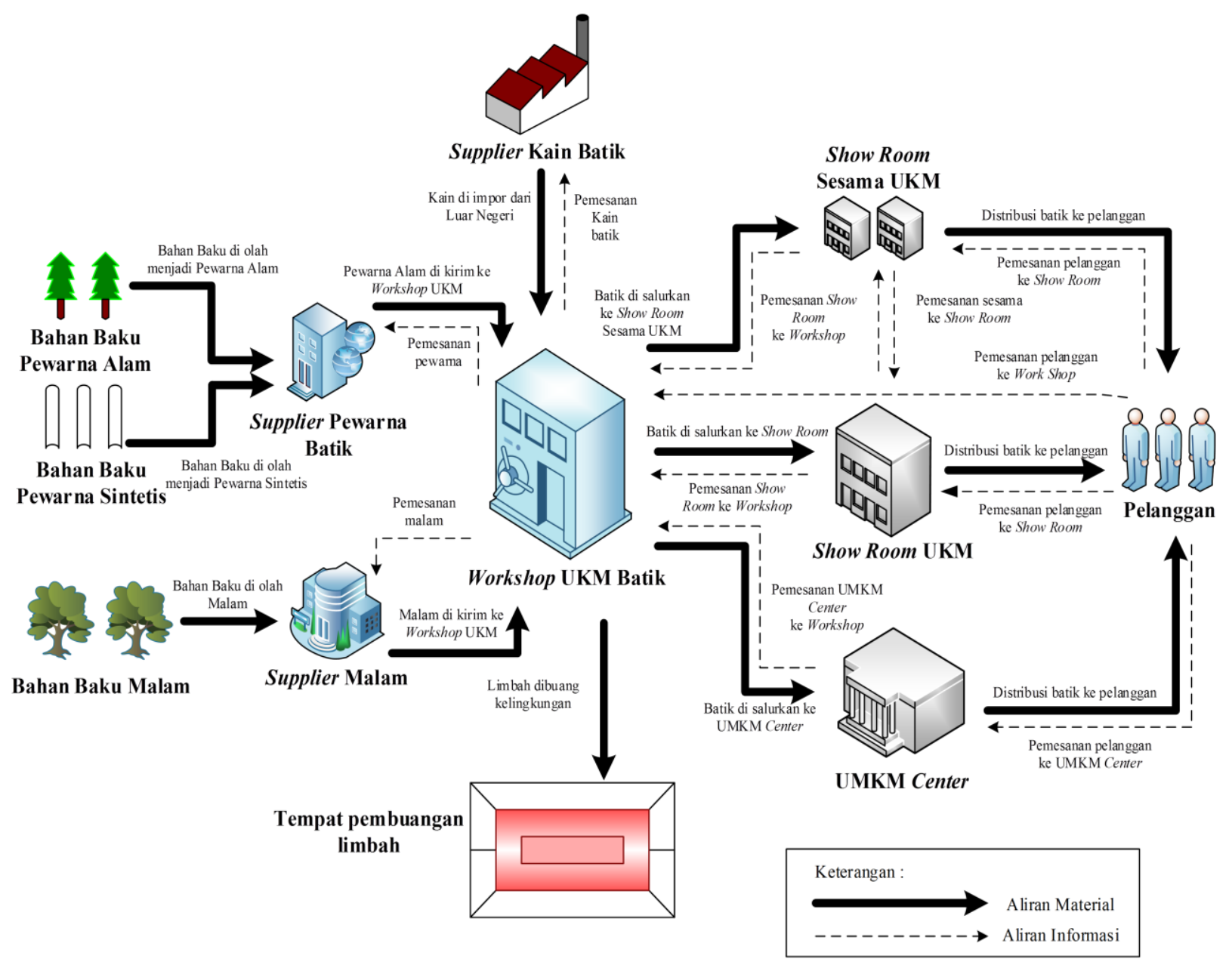

Gambar 2. Peta sistem UKM batik Kota Semarang

Tabel 1. SWOT keberlanjutan sentra UKM Batik kota Semarang

\begin{tabular}{|c|c|c|c|}
\hline \multirow[t]{2}{*}{ kriteria } & \multicolumn{2}{|c|}{ Kondisi UKM Batik saat ini } & Prediksi kondisi masa mendatang \\
\hline & Kekuatan & Kelemahan & Peluang $\quad$ Ancaman \\
\hline $\begin{array}{l}\text { 1. Lingkungan } \\
\text { 1.1.Optimasi umur sistem } \sqrt{ } \\
\text { 1.2. Pengurangan transportasi } \\
\text { 1.3. Penggunaan sumber daya } \\
\text { 1.4. Minimasi limbah } \sqrt{ } \\
\text { 1.5. Konservasi/bio compatibility } \\
\text { 1.6. Toksisitas - }\end{array}$ & $\begin{array}{l}\text { Peralatan yang } \\
\text { digunakan memiliki } \\
\text { masa pakai yang lama } \\
\text { Penggunaan bahan } \\
\text { beracun hanya dalam } \\
\text { jumlah sangat kecil }\end{array}$ & $\begin{array}{l}\text { Pengelolaan limbah } \\
\text { belum terpadu } \\
\text { Penggunaan bahan } \\
\text { pewarna sintetis lebih } \\
\text { dominan dari pewarna } \\
\text { alam }\end{array}$ & $\begin{array}{ll}\text { Limbah bahan baku } & \text { Limbah produksi } \\
\text { dapat dimanfaatkan } & \text { mencemari } \\
\text { kembali } & \text { lingkungan } \\
\text { Limbah pewarna } & \\
\text { alam untuk pupuk } & \\
\text { tanaman } & \end{array}$ \\
\hline $\begin{array}{l}\text { Sosial budaya } \\
\text { 2.1. Tanggung jawab sosial } \\
\text { 2.2. K3 } \sqrt{ } \\
\text { 2.3. Kondisi keadaan lingkungan } \\
\text { 2.4. Ketenaga-kerjaan } \sqrt{ } \\
\text { 2.5. Hubungan industri } \\
\text { 2.6. Keragaman budaya } \sqrt{ }\end{array}$ & $\begin{array}{l}\text { Dapat diterima oleh } \\
\text { berbagai budaya dan } \\
\text { daerah } \\
\text { Meningkatkan sosial } \\
\text { ekonomi masyarakat }\end{array}$ & $\begin{array}{l}\text { Terjadi penurunan } \\
\text { jumlah tenaga kerja } \\
\text { Terdapat resiko K3 } \\
\text { karena penggunaan } \\
\text { bahan kimia }\end{array}$ & $\begin{array}{ll}\text { Membuka lapangan } & \text { Belum } \\
\text { kerja baru } & \text { dikuasainya } \\
\text { Jumlah pembatik } & \text { pengetahuan } \\
\text { Semarang meningkattentang motif/ } & \text { gambar yang } \\
& \text { sesuai selera } \\
& \text { masyarakat yang } \\
& \text { cepat berubah } \\
\end{array}$ \\
\hline $\begin{array}{l}\text { Ekonomi } \\
\text { 3.1. Posisi pasar dan daya saing } \\
\text { 3.2. Profitabilitas } \\
\text { 3.3. Nilai tambah pelanggan } \sqrt{ } \\
\text { 3.4. Pengembangan bisnis } \\
\text { 3.5. Kemitraan/ kerjasama } \sqrt{ } \\
\text { 3.6. Efek ekonomi makro }\end{array}$ & $\begin{array}{l}\text { Nilai tambah yang } \\
\text { diperoleh pelanggan } \\
\text { cukup tinggi } \\
\text { Dukungan penuh dari } \\
\text { pemerintah }\end{array}$ & $\begin{array}{l}\text { Posisi pasar lebih } \\
\text { rendah dibanding } \\
\text { pesaing } \\
\text { Belum ada supplier } \\
\text { bahan baku yang } \\
\text { berlokasi di Semarang }\end{array}$ & $\begin{array}{l}\text { Bantuan peralatan } \\
\text { baru dan pelatihan } \\
\text { dari pemerintah } \\
\text { Peningkatan } \\
\text { pendapatan } \\
\text { masyarakat } \\
\text { konsumen }\end{array}$ \\
\hline
\end{tabular}


Tabel 2. Hasil penilaian keberlanjutan UKM Batik kota Semarang

\begin{tabular}{|c|c|c|c|c|c|c|c|c|c|c|c|c|c|}
\hline No & UKM & $\begin{array}{c}\text { UKM } \\
1\end{array}$ & $\begin{array}{l}\text { UKM } \\
2\end{array}$ & $\begin{array}{l}\text { UKM } \\
3\end{array}$ & $\begin{array}{c}\text { UKM } \\
4\end{array}$ & $\begin{array}{l}\text { UKM } \\
5\end{array}$ & $\begin{array}{l}\text { UKM } \\
6\end{array}$ & UKM 7 & UKM 8 I & JKM 9 & $\begin{array}{l}\text { Total } \\
\text { nilai }\end{array}$ & $\begin{array}{l}\text { Rata- } \\
\text { rata }\end{array}$ & \\
\hline \multicolumn{14}{|c|}{ 1. Dimensi lingkungan } \\
\hline 1.1. & Optimasi umur sistem & 0,5 & 0,25 & 0,5 & 0,5 & 0,5 & 0,5 & 0,5 & 0,5 & 0,5 & 4,25 & 0,47 & \\
\hline 1.2 & Pengurangan transportasi & 0 & 0 & 0 & 0 & 0 & 0,33 & 0 & 0 & 0,33 & 0,66 & 0,07 & \\
\hline 1.3 & Penggunaan sumber daya & 0,75 & 0,5 & 0,75 & 1 & 0,25 & 0,25 & 1 & 0,75 & 0,5 & 5,75 & 0,64 & \\
\hline 1.4 & Minimasi limbah & 0,5 & 0 & 0,5 & 0,5 & 0,5 & 0,5 & 0,5 & 0,5 & 0 & 3,50 & 0,39 & \\
\hline 1.5 & $\begin{array}{l}\text { Konservasi/bio- } \\
\text { compatibility }\end{array}$ & 0,66 & 0,66 & 0,66 & 0,66 & 0,66 & 0,66 & 0,66 & 0,66 & 0,66 & 5,94 & 0,66 & \\
\hline 1.6 & Toksisitas & 0 & 0,33 & 0 & 0 & 0 & 0 & 0 & 0 & 0 & 0,33 & 0,04 & \\
\hline & Rata-rata & 0,40 & 0,29 & 0,40 & 0,44 & 0,32 & 0,37 & 0,44 & 0,40 & 0,33 & 3,41 & 0,38 & $\mathrm{M}$ \\
\hline \multicolumn{14}{|c|}{ 2. Dimensi sosial budaya } \\
\hline 2.1 & Tanggung jawab s & 0 & 0 & 0 & 0 & 0 & 0 & 0 & 0 & 1 & 1,00 & 0,11 & \\
\hline 2.2 & $\mathrm{~K} 3$ & 0 & 0 & 1 & 1 & 0 & 0 & 1 & 1 & 1 & 5,00 & 0,56 & $\mathrm{M}$ \\
\hline 2.3 & $\begin{array}{l}\text { Kondisi keadaan } \\
\text { lingkungan }\end{array}$ & 0 & 0,25 & 0,25 & 0 & 0,25 & 0,25 & 0 & 0,25 & 0 & 1,25 & 0,14 & \\
\hline 2.4 & Ketenag & 1 & 0 & 1 & 0,5 & 0 & 0 & 0 & 0,5 & 0 & 3,00 & 0,33 & \\
\hline 2.5 & Hubuns & 0 & 0 & 0,25 & 0 & 0,5 & 0 & 0 & 0,25 & 0 & 1,00 & 0,11 & \\
\hline 2.6 & Keragaman budaya & 0 & 0 & 0,33 & 0 & 0 & 0,33 & 0 & 0 & 0 & 0,66 & 0,07 & $\mathrm{~L}$ \\
\hline & Rata-rata & 0,17 & 0,04 & 0,47 & 0,25 & 0,13 & 0,10 & 0,17 & 0,33 & 0,33 & 1,99 & 0,22 & $\mathrm{~L}$ \\
\hline \multicolumn{14}{|c|}{ 3. Dimensi ekonomi } \\
\hline 3.1 & Posisi pasar da & 0 & 0,33 & 0,33 & 0,33 & 0,33 & 30,33 & 0,33 & 0,33 & 0,66 & 2,97 & 0,33 & \\
\hline 3.2 & Profitabilitas & 0,33 & 0,33 & 0,66 & 0,33 & 0,66 & 0 & 0 & 0,66 & 0 & 2,97 & 0,33 & \\
\hline 3.3 & Nilai tambah pela & 0 & 0 & 0,33 & 0,33 & 0,33 & 0,33 & 0 & 0 & 0,33 & 1,65 & 0,18 & \\
\hline 3.4 & Pengembangan bi & 0 & 0,25 & 0,25 & 0 & 0 & 0,5 & 0 & 0 & 0,25 & 1,25 & 0,14 & \\
\hline 3.5 & Kemitraan/ k & 0 & 0,33 & 0,33 & 0,33 & 0,33 & 0,33 & 0,33 & 0,33 & 0,33 & 2,64 & 0,29 & \\
\hline & Efek ekonomi ma & 0 & 0 & 0 & 0 & 0 & 0 & 0 & 0 & 0 & 0,00 & 0,00 & \\
\hline \multirow{2}{*}{\multicolumn{2}{|c|}{$\begin{array}{r}\text { Rata-rata } \\
\text { Nilai rata-rata }\end{array}$}} & 0,06 & 0,21 & 0,32 & 0,22 & 0,28 & 0,25 & 0,11 & 0,22 & 0,26 & 1,91 & 0,21 & \\
\hline & & 0,21 & 0,18 & 0,40 & 0,30 & 0,24 & 0,24 & 0,24 & 0,32 & 0,31 & 2,43 & 0,27 & \\
\hline
\end{tabular}

Tabel 2 menunjukkan kalau nilai keberlanjutan UKM batik kota Semarang masih rendah. Nilai rata-rata keberlanjutan dari tiap UKM adalah 0,27. Dimensi lingkungan dan sosial budaya memiliki banyak nilai nol yang berarti kriteria-kriteria yang disebutkan dalam PSS belum diterapkan dalam sistem UKM batik. Nilai tingkat keberlanjutan yang masih rendah tersebut menunjukkan bahwa UKM batik memerlukan pengembangan untuk meningkatkan level keberlanjutannya, maka perlu dilakukan perumusan rekomendasi sebagai langkah berikutnya dari metode PSS.

\section{Perumusan Alternatif Rekomendasi}

Perumusan alternatif rekomendasi dibuat untuk mengatasi permasalahan yang terjadi pada kriteria yang memiliki kategori High dan Medium. Kedua kategori tersebut berarti kriteria yang dinilai memiliki peran yang penting bagi UKM karena responden banyak memberi jawaban "Ya" untuk pertanyaan tentang apakah ada masalah terkait kriteria tersebut. Perumusan rekomendasi dilakukan dengan bantuan worksheet 3 dari PSS dan perumusan detail rekomendasi menggunakan lembar kerja (worksheet) 9. Kedua panduan tersebut telah dilakukan proses terjemah dari bahasa Inggris ke dalam bahasa Indonesia dan dilakukan penyesuaian agar dapat digunakan untuk industri kecil di
Indonesia tapi tanpa melakukan perubahan yang substantif. Dari hasil kuisioner didapatkan 7 alternatif rekomendasi.

Pada dimensi lingkungan diberikan 5 rekomendasi, 3 diantaranya pada kriteria penggunaan sumber daya yaitu (1) optimalisasi penggunaan bahan baku (air untuk mencuci kain bekas pewarnaan) (2) outsourcing untuk memenuhi peningkatan permintaan batik dan (3) penggunaan kolektif peralatan produksi batik. Selain itu juga perlu dilakukan (4) daur ulang dari bahan baku produk seperti malam dan pewarna dan (5) menerapkan batik dengan bahan baku bio-degradable. Pada dimensi sosial budaya diberikan 2 rekomendasi yaitu (1) Menggunakan alat pelindung diri dan (2) Memberikan papan petunjuk K3. Pada dimensi ekonomi tidak diberikan rekomendasi karena nilai rata-rata penilaian keberlanjutan pada dimensi ini berada pada kategori L dan N.

\section{Penilaian Alternatif Rekomendasi}

Setelah alternatif rekomendasi sudah dirumuskan, langkah selanjutnya adalah membandingkan alternatif rekomendasi tersebut dengan kondisi dari UKM Batik Kota Semarang yang ada saat ini. Apakah alternatif rekomendasi tersebut dapat membuat UKM Batik Kota Semarang menjadi jauh 
lebih baik, lebih baik saja, sama saja, atau bahkan lebih buruk dari kondisi saat ini. Untuk membandingkan alternatif rekomendasi dilakukan dengan wawancara dengan pemilik UKM Batik Kota Semarang. Rekomendasi yang menurut pendapat pengelola UKM tidak akan cukup berarti perbaikannya diberi nilai minus (-) dan sama dengan (=). Arti dari nilai yang diberikan oleh responden dijelaskan dengan Tabel 3 dan hasil perbandingan alternatif rekomendasi dapat dilihat pada Tabel 4.

Tabel 3. Penilaian rekomendasi dari aspek kemudahan pelaksanaan dan jangka waktu.

\begin{tabular}{|c|c|c|c|}
\hline $\begin{array}{l}\text { Kemudahan } \\
\text { penerapan }\end{array}$ & $\begin{array}{c}\text { Jangka waktu } \\
\text { pelaksanaan } \\
\text { yang dibutuhkan }\end{array}$ & Nilai & Arti \\
\hline Sulit & Panjang & - & Buruk \\
\hline Sulit & Panjang & $=$ & Sama \\
\hline Mudah & Pendek & + & Lebih baik \\
\hline Mudah & Pendek & ++ & $\begin{array}{c}\text { Jauh lebih } \\
\text { baik }\end{array}$ \\
\hline
\end{tabular}

Tabel 4. Perbandingan alternatif rekomendasi

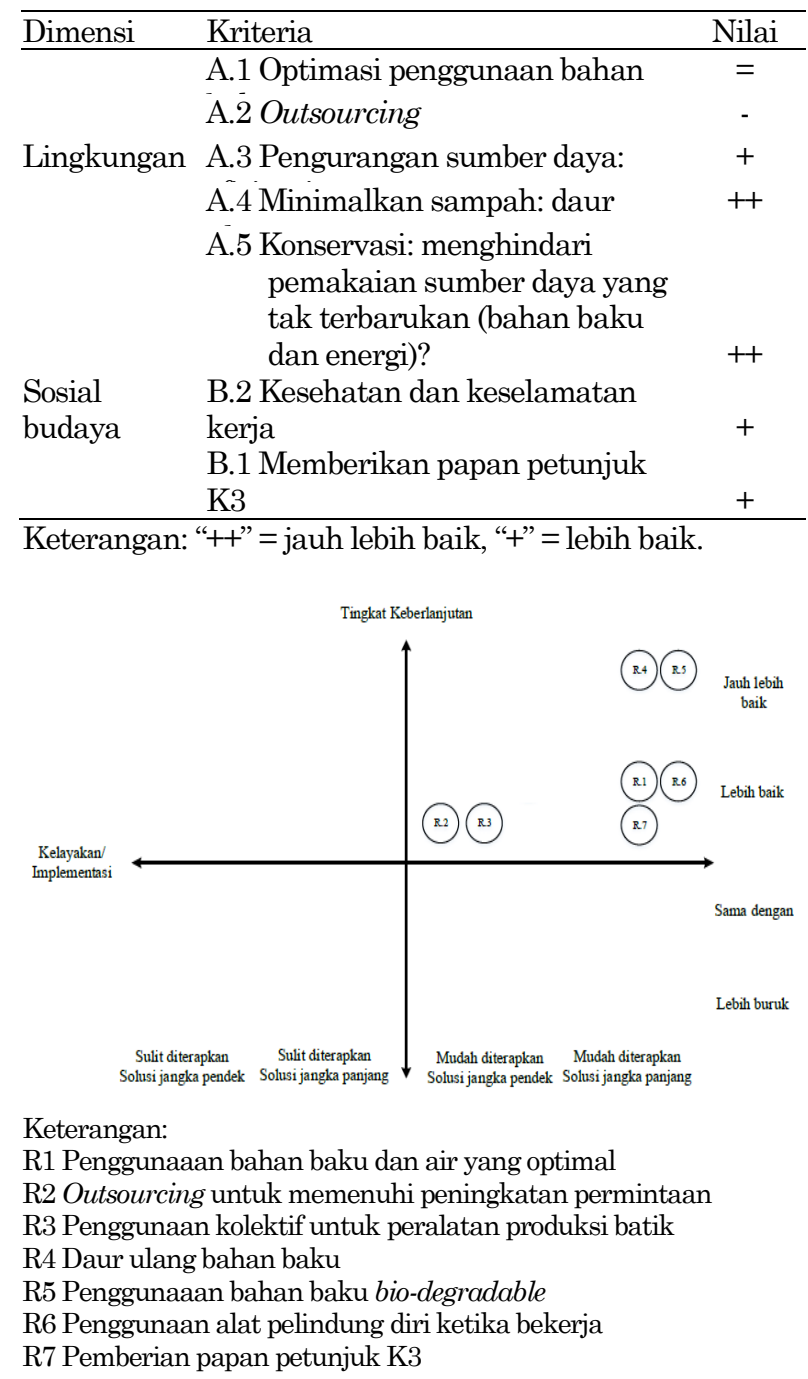

Gambar 3. Diagram kelayakan rekomendasi
Dari Tabel 4 dapat dilihat bahwa alternatif rekomendasi yang dirumuskan untuk dimensi lingkungan dan ekonomi dapat memberikan dampak yang jauh lebih baik, sedangkan untuk dimensi sosial budaya dapat memberikan dampak yang lebih baik terhadap UKM Batik Kota Semarang jika alternatif rekomendasi tersebut diterapkan.

\section{Menentukan Rekomendasi Terpilih}

Selain dari segi dampaknya terhadap perbaikan sistem jika diterapkan, alternatif rekomendasi juga dinilai dari segi feasibility untuk diterapkan (UNEP [6]). Seluruh alternatif rekomendasi yang telah dibandingkan dengan kondisi UKM Batik Kota Semarang saat ini, kemudian dilakukan pengujian kelayakan untuk mengetahui seberapa sulit alternatif rekomendasi untuk diterapkan. Rekomendasi ini dibandingkan dengan menggunakan diagram kelayakan rekomendasi. Diagram kelayakan rekomendasi dapat dilihat pada Gambar 3 .

Pada Gambar 3 dapat dilihat bawa alternatif rekomendasi yang dirumuskan semua berada pada kuadran yang sama. Rekomendasi yang memiliki nilai terbaik adalah yang berada pada bagian kanan atas pada posisi paling jauh dari nilai nol. Rekomendasi tersebut adalah daur ulang bahan dan material limbah (R4) dan penggunaan bahan baku biodegradable (R5). Berikutnya adalah optimalisasi penggunaan bahan baku (R1), penggunaan APD untuk menghindari kecelakaan kerja (R6) dan pemberian papan petunjuk K3 (R7). Rekomendasi tersebut

Untuk menggambar radar keberlanjutan dibutuhkan 6 butir rekomendasi. Dari hasil wawancara diperoleh 6 rekomendasi untuk dimensi ekonomi. Untuk kriteria Posisi Pasar dan Daya Saing dirumuskan 3 rekomendasi yaitu (1) Mengidentifikasi kelompok sasaran dan memenuhi kebutuhan pelanggan, (2) Menerapkan strategi yang menghasilkan produk lebih menarik bagi pelanggan dan (3) Menciptakan dan menambahkan produk terkait diversifikasi pada penawaran batik. Sedangkan untuk kriteria Profitabilitas/Nilai tambah diberikan rekomendasi (1) Meningkatkan value chain di seluruh sistem dalam rantai produksi mulai distribusi bahan baku sampai akhir dari penggunaan batik, (2) Outsourcing untuk kegiatan yang lebih khusus, dan (3) Meningkatkan organisasi, memotivasi pekerja dengan pelatihan. Pada dimensi ekonomi ada beberapa rekomendasi yang memiliki nilai + dan ++, yaitu (1) Posisi pasar dan daya saing (++) dan Profitabilitas / Nilai tambah untuk perusahaan dan konsumen (+). 


\section{Rekomendasi untuk Meningkatkan Tingkat Keberlanjutan}

Setelah merumuskan alternatif kemudian rekomendasi akan dirinci menjadi rekomendasi yang detail dan jelas. Untuk kriteria penggunaan sumber daya direkomendasikan agar penggunaan bahan baku/ energi lebih dioptimalkan (R.1). Pada industri batik penggunaan sumber daya berupa air untuk mencuci kain hasil pewarnaan menghasilkan limbah kimia bagi lingkungan. Penggunaan bahan kimia juga sebenarnya dapat diganti dengan pewarna alami. Pada sistem saat ini masih terjadi pemborosan karena para pengrajin batik masih belum memahami cara menghemat penggunaan bahan baku dan energi. Menurut Avivah [15], kadar pengunaan pewarna alam yang tepat adalah $0,125 \mathrm{~kg}$ untuk 1 potong kain batik tulis dan $0,02 \mathrm{~kg}$ untuk 1 potong kain batik cap. Kadar malam yang tepat untuk produksi batik yaitu $0,094 \mathrm{~kg}$ untuk 1 potong kain batik tulis dan $0,04 \mathrm{~kg}$ untuk 1 potong batik cap. Untuk penggunaan air, volume air yang optimal untuk proses pembuatan batik tulis yaitu 45,71 liter per potong kain, sedangkan untuk proses pembuatan batik cap yaitu 45 liter per potong kain yang dicap.

Rekomendasi pada kriteria minimasi limbah dilakukan dengan daur ulang dari bahan baku produk seperti malam dan pewarna. Untuk mengurangi timbunan sampah hasil proses produksi batik, maka kegiatan daur ulang perlu dilakukan. Limbah pewarna sintetis menghasilkan limbah berupa cairan dan endapan yang jika dikeringkan dapat memadat. Setelah dilakukan filterisasi untuk mengurangi risiko racun yang ditimbulkan, padatan endapan limbah pewarna sintetis ini dapat digunakan untuk membuat produk seperti pot. Limbah lain seperti malam juga dapat di daur ulang dengan melakukan penyaringan malam saat proses nglorod (melepas keseluruhan malam dari kain dengan perebusan dalam air panas) dilakukan. Pengolahan limbah dilakukan dengan memanfaatkan peralatan proses produksi yang sudah tersedia yaitu kowen dalam tanah atau penyaring malam yang terdapat pada UKM batik. Hasil buangan akhir limbah ini berupa air yang dapat langsung dibuang ke saluran air.

Pada kriteria konservasi direkomendasikan untuk menggunakan bahan baku produksi yang bersifat bio-degradable. Bahan baku produksi batik yang bersifat bio-degradable (dapat terurai langsung oleh alam) yaitu pewarna alam. Penggunaan bahan baku yang bersifat bio-degradable ini sangat mendukung kelestarian lingkungan karena pembuangan limbah bahan baku ini dapat langsung diurai oleh alam tanpa menyebabkan efek negatif terhadap ling- kungan. Berbeda dengan pewarna sintetis yang jika dibuang langsung ke lingkungan tidak dapat langsung terurai oleh alam dan berbahaya untuk ekosistem lingkungan. Pengaruh langsung pewarna alam terhadap lingkungan adalah tidak mencemari air yang ada di lingkungan yang dipakai untuk keperluan sehari-hari.

Pada dimensi sosial budaya masalah yang ditemukan hanya terkait dengan keselamatan dan kesehatan kerja selama proses produksi berlangsung. Rekomendasi yang diberikan adalah melengkapi pekerja dengan pakaian berlengan panjang, masker dan sarung tangan dapat melindungi diri dari masalah kesehatan dan keselamatan kerja pada proses produksi batik tulis.

\section{Radar Keberlanjutan}

Pada tahap ini, kriteria yang sudah dikategorikan sesuai skornya kemudian divisualisasikan ke dalam sebuh radar keberlanjutan. Hasil perbandingan rekomendasi yang telah dilakukan pada tahap sebelumnya divisualisasikan pada radar. Kriteria yang memiliki skor "++" akan digambarkan dengan radar yang paling tajam keluar. Pembuatan radar keberlanjutan ini menggunakan software Sustainability Design Orienting Toolkit (SDO Toolkit). Radar keberlanjutan untuk dimensi lingkungan diberikan pada Gambar 4, dimensi sosial budaya pada Gambar 5 dan dimensi ekonomi pada Gambar 6.

Pada Gambar 4 dapat dilihat bahwa kriteria yang memiliki kategori medium yaitu kriteria optimasi umur sistem, pengurangan sumber daya, minimasi sampah dan konservasi. Kriteria yang memiliki bentuk ujung radar yang paling tajam adalah kriteria minimasi sampah dan konservasi karena memiliki skor "++" yang artinya jauh lebih baik jika diterapkan. Untuk kriteria pengurangan sumber daya didapatkan bahwa hasil perbandingannya memiliki skor "+" yang berarti jika rekomendasi tersebut diterapkan maka akan membuat sistem yang lebih baik dari sebelumnya.

Pada Gambar 5 yaitu gambar radar keberlanjutan dimensi sosial budaya, dapat dilihat bahwa kriteria yang memiliki bentuk ujung radar yang paling tajam adalah kriteria kesehatan dan keselamatan kerja yang dituliskan dengan kriteria "Empower/ valorize local resources" pada software SDO Toolkit karena kriteria tersebut setelah dibandingkan dengan sistem saat ini hasil perbandingannya memiliki skor "+" yang berarti jika rekomendasi tersebut diterapkan maka akan membuat sistem lebih baik dari sebelumnya. Kriteria ini memiliki kategori medium sehingga dibutuhkan alternatif rekomendasi untuk mengatasi masalah yang terjadi pada kriteria ini. 


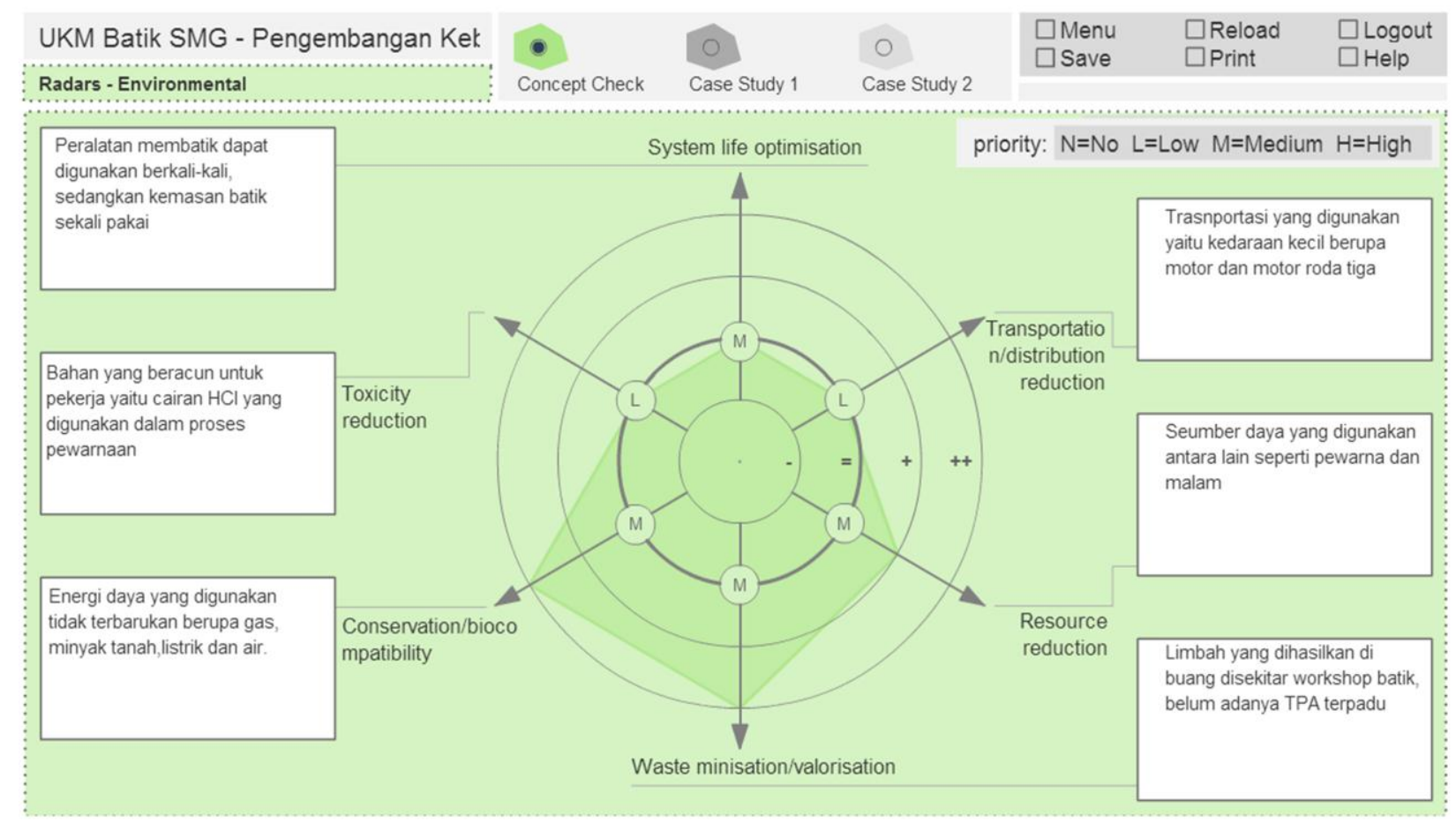

Gambar 4. Radar keberlanjutan dimensi lingkungan

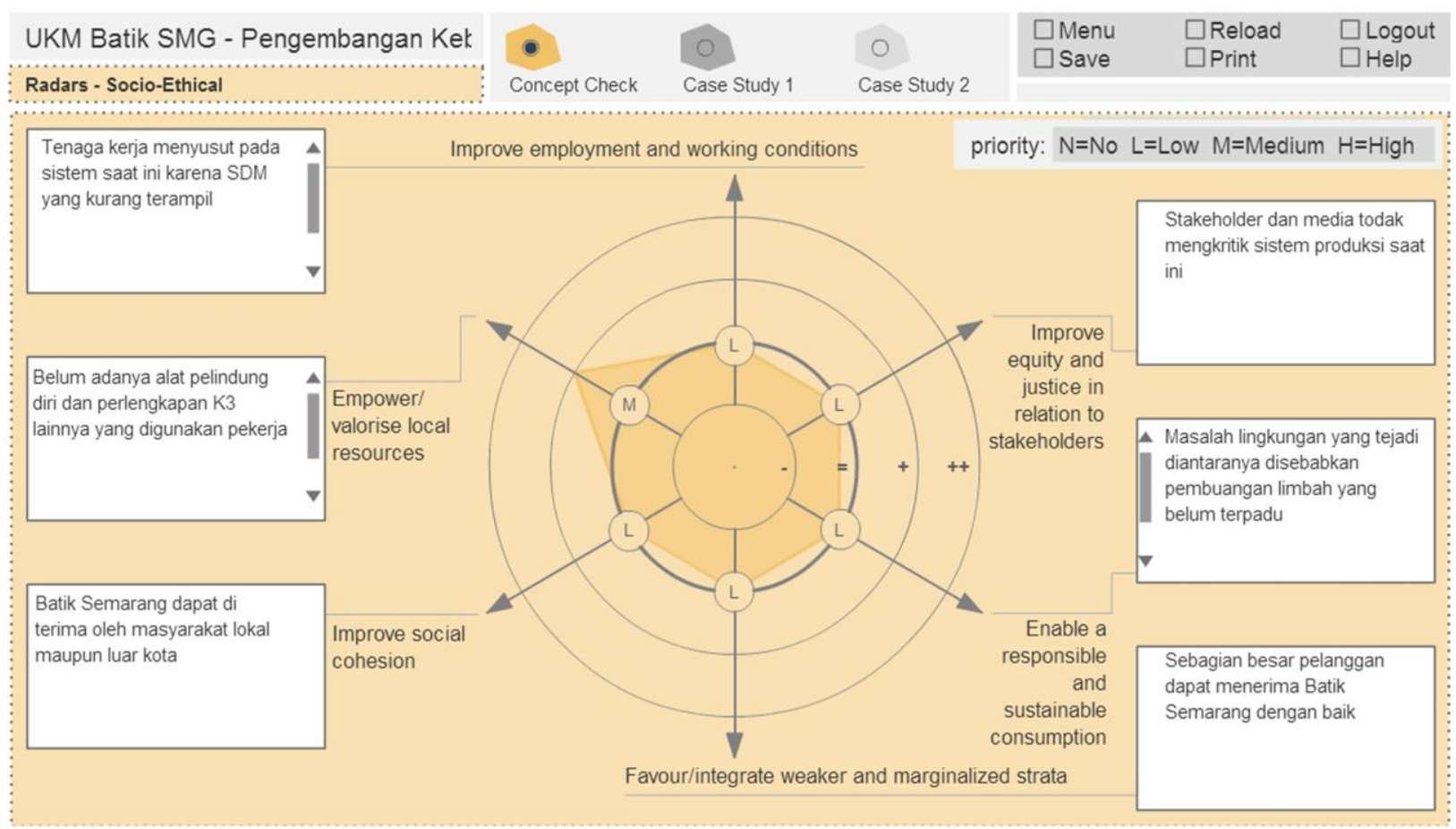

Gambar 5. Radar keberlanjutan dimensi sosial budaya

Pada Gambar 6 yaitu gambar radar untuk dimensi ekonomi, dapat dilihat bahwa kriteria yang memiliki bentuk ujung radar yang paling tajam adalah posisi pasar dan daya saing. Hal ini disebabkan karena setelah dibandingkan dengan sistem saat ini didapatkan bahwa hasil perbandingannya memiliki skor “++" yang berarti jika rekomendasi tersebut diterapkan maka akan membuat sistem jauh lebih baik dari sebelumnya. Walaupun kriteria ini memiliki kategori Low, tetapi kriteria ini perlu dikembangkan untuk mengatasi masalah yang terjadi pada kriteria ini. Kemudian rekomendasi kriteria lain yaitu kriteria profitabilitas didapatkan skor “+” yang berarti jika rekomendasi tersebut diterapkan maka akan membuat sistem lebih baik dari sebelumnya. 


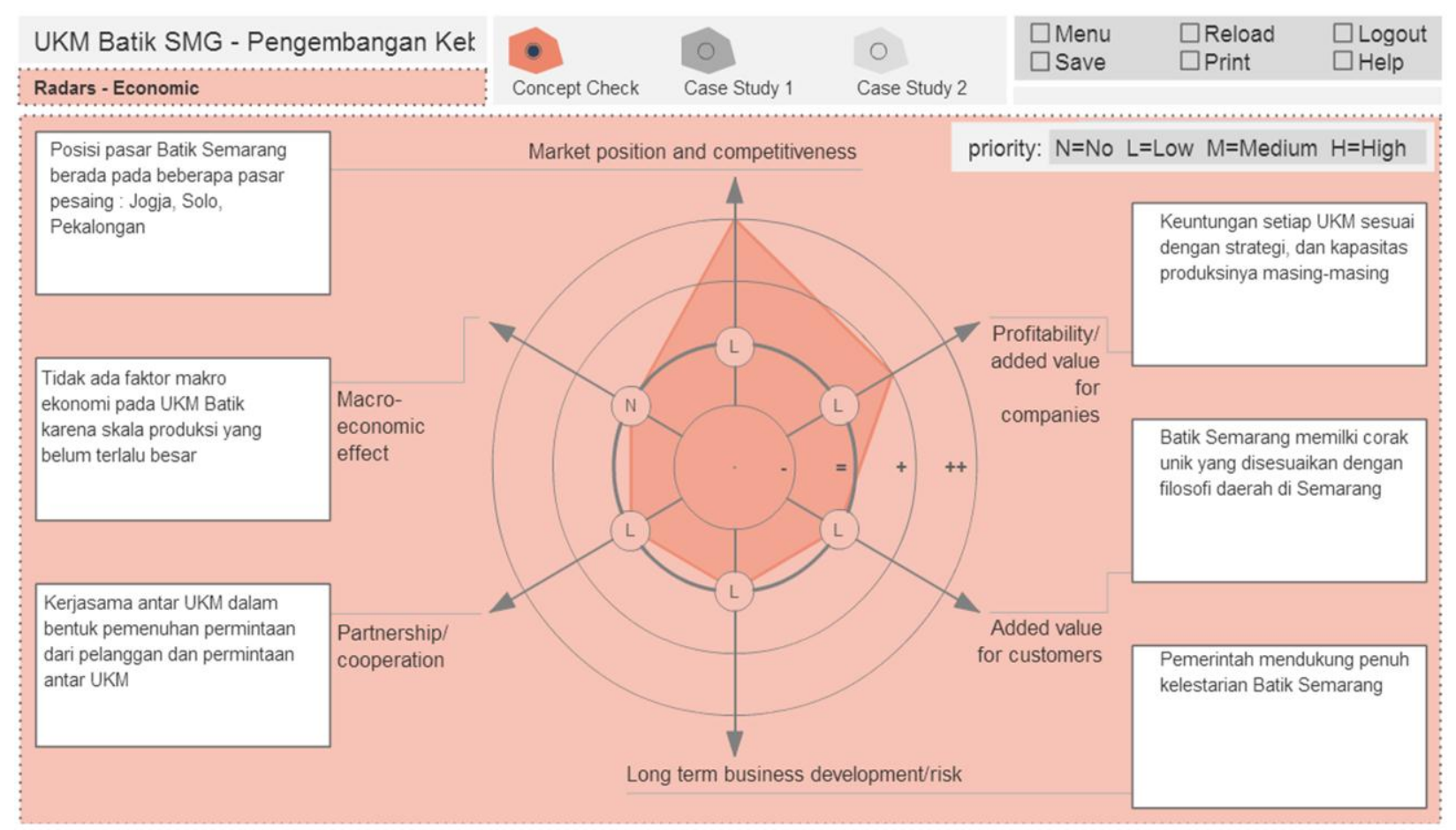

Gambar 6. Radar keberlanjutan dimensi ekonomi

\section{Simpulan}

Hasil pengukuran tingkat keberlanjutan UKM batik kota Semarang memberikan nilai rata-rata 0,103 yang berarti masih dalam kategori rendah. Perlu dilakukan pengembangan UKM untuk meningkatkan keberlanjutannya. Peluang pengembangan sistem produksi UKM Batik Kota Semarang dapat di lihat dari kriteria pada tiap dimensi keberlanjutan yang memiliki prioritas untuk dikembangkan. Kriteria yang diprioritaskan untuk dikembangkan merupakan kriteria yang memiliki kategori medium yaitu kriteria yang memiliki skor antara 0,34-0,66. Alternatif rekomendasi pada kriteria yang telah dilakukan pengujian dan evaluasi dengan keadaan yang jauh lebih baik jika diterapkan dan memiliki kemungkinan diterapkan untuk solusi jangka panjang.

Pada dimensi lingkungan kriteria yang masuk dalam kategori medium adalah (1) pengurangan penggunaan sumber daya $(0,64)$, (2) minimasi limbah (0,39), dan (3) konservasi $(0,66)$. Sedangkan dari dimensi sosial budaya adalah kriteria kesehatan dan keselamatan kerja (0,56). Minimasi limbah dilakukan dengan daur ulang dari bahan baku produk, konservasi dengan penggunaan bahan baku bio-degradable, dan memperbaiki posisi pasar dan daya saing dengan mengidentifikasi pasar sasaran, menghasilkan produk lebih menarik bagi pelanggan, dan menciptakan diversifikasi pada penawaran batik.

\section{Daftar Pustaka}

1. WCED, Our Common Future the Brundlandt Report. Oxford University Press, 1987.

2. Palosuo, T., Suominen, T., Werhahn-Mess, W., Gonzalo, J. G., and Lindner, M., Assigning Results of the Tool for Sustainability Impact Assessment (ToSIA) to Products of a ForestWood-Chain, Ecological Modelling, 221, 2010, pp. 2215-2225.

3. Jager, D. T., Vermeire, T. G., Slooff, W., and Roelfzema, H., Uniform System for the Evaluation of Substances II Effects Assessment, Chemosphere, 29(2), 1994, pp. 319-335.

4. Angelakoglou, K., Gaidajis, G., A Review of Methods Contributing to the Assessment of the Environmental Sustainability of Industrial Systems, Journal of Cleaner Production, 108, Part A, 2015, pp. 725-747.

5. Azapagic, A., Developing a Framework for the Sustainable Development Indicators for the Mining and Minerals Industry, Journal of Cleaner Production, 12(6), 2004, pp. 639-662.

6. UNEP and DELFT University of Technology. Design for Sustainability: A Step by Step Approach, Report, 2009.

7. Tischner, I., Fat Lives: A Feminist Psychological Exploration. Routledge, London, 2013.

8. Crul, A. and Diehl, Design for Sustainability: A Practical Approach for Developing Economies. Paris: United Nations Environment Program (UNEP), 2007. 
9. Andayani, S., Tjahyono, E., dan Sajio, Peningkatan Kuantitas dan Kualitas Produk pada Perajin Batik Dukuh Kupang Kota Surabaya. Jurnal Pengabdian LPPM Untag Surabaya, (1), 2014, pp. 41-51.

10. Djoemena, N. S., Ungkapan Sehelai Batik, Penerbit Djambatan, Jakarta, 1990.

11. Soekardan, D., dan Juju, U. Analisis Lingkungan Perusahaan dan Strategi Perusahaan serta Dampaknya pada Kinerja UMK Batik, Jurnal Trikonomika, 11, 2012, pp. 183-194.

12. Kurniawan, M.W., Purwanto, P., Sudarno, S., Strategi Pengelolaan Air Limbah Sentra UMKM Batik yang Berkelanjutan di Kabupaten Sukoharjo, Jurnal Ilmu Lingkungan, 11(2), 2013, pp. 62-72.
13. Putranti, Model Pemetaan CSR untuk Menunjang UKM Mendapatkan Enterpreneur Unggul dan Sustainable (Studi UKM Batik Pekalongan), Jurnal Ilmiah Serat Acitya, 2(3), 2013, 47-61.

14. Purwaningsih, R., Product Service Systems Method on Jepara Furniture Industry Sustainability Assessment, Proceeding of International Conference on Electric vehicular Technology and Industrial, Mechanical, electrical, Chemical Engineering, Surakarta, Desember 2015, pp. 5C2.1.1-6.

15. Arikunto, S., Prosedur Penelitian Suatu Pendekatan Praktek. PT. Rineka Cipta, Jakarta, 1998.

16. Avivah, N., dan Rinawati, D.I., Studi Empiris Perbedaan Efisiensi Produksi Pada UKM Batik Cap yang Belum dan Telah Tersertifikasi SNI Batik, Seminar nasional ACISE, Semarang 2014. 